\title{
Predation on the Rosario Red-legiged Frog, Eleutherodactylus zugi (Eleutherodactylidae), by the Cuban Mosquitofish, Gambusia punctata (Poeciliidae) in western Cuba
}

\author{
Tomás M. Rodríguez-Cabrera ${ }^{1}$ and Rodet Rodríguez Silva ${ }^{2}$
}

1Jardín Botánico de Cienfuegos, Pepito Tey, Cienfuegos, CP 59290, Cuba (tomasmichel.rodriguez@gmail.com)

${ }^{2}$ División de Zoología de Vertebrados, Instituto de Ecología y Sistemática, La Habana, CP 10800, Cuba (rodet@ecologia.cu and rodetrodriguezsilva@gmail.com)

Photographs by the senior author.

$\mathrm{T}^{\mathrm{s}}$ he Cuban Archipelago harbors among the greatest diversity and endemism in the frog genus Eleutherodactylus (Eleutherodactylidae) in the West Indies, with 59 species, $98.3 \%$ of which are endemic (Estrada 2012; Rivalta et al. 2014; Díaz and Hedges 2015). This is exceeded only by Hispaniola, with 65 native species, all of which are endemic (Henderson and Powell 2009; Powell 2012; Incháustegui et al. 2015). Several predators have been reported for adults and eggs of these frogs in the insular Caribbean, including insects (Megaselia, Paratrechina, Linepithema, Amphiacusta), arachnids (Avicularia, Ctenus, Mastigoproctus, Ohvida, Olios, Phrynus, Stasina, Tityus, and ctenizid and corinnid spiders), centipedes (Scolopendra), millipedes (Liomus), snails (Caracolus, Polydontes, Subulina), frogs (Eleutherodactylus, Osteopilus), lizards (Ameiva, Anolis, Sphaerodactylus, Thecadactylus), snakes (Alsophis, Arrhyton, Borikenophis, Caraiba, Chilabothrus, Chironius, Corallus, Cubophis, Erythrolamprus, Hypsirhynchus, Ialtris, Magliophis, Mastigodryas, Tropidophis), birds (Bubulcus, Buteo, Margarops, Melanerpes, Megascops, Coccyzus, Turdus), and mammals (Felis, Rattus, Urva; see Henderson and Powell 2009 for a review). Nonetheless, these predators have been reported for only 23 species of Eleutherodactylus (for a review see Henderson and Powell 2009; Alfonso et al. 2013; Díaz et al. 2015), which represent a low proportion (14\%) with respect to the approximately 165 species occurring in the West Indies. However, native fishes have not been reported preying either on Eleutherodactylus or any other frogs in the West Indies.

In Cuba, predators have been confirmed only for six species of Eleutherodactylus (10\%): E. atkinsi, E. cuneatus, E. dimidiatus, E. iberia, E. cf. thomasi, and E. zugi (for a review see Henderson and Powell 2009, but also Alfonso et al. 2013; Díaz et al. 2015). The Rosario Red-legged Frog, Eleutherodactylus zugi (Fig. 1), is a small $(20 \mathrm{~mm})$, rela- tively common endemic distributed in the Guaniguanico Mountain Range, Artemisa and Pinar del Río Provinces in western Cuba (Díaz and Cádiz 2009; Rivalta et al. 2014). It is always associated with forested areas, where it inhabits leaf litter, occurs under rocks and fallen logs, and occupies limestone holes (Díaz and Cádiz 2009). This species is considered Endangered on the IUCN Red List (Hedges and Díaz 2004, 2011). Consequently, an awareness of all potential threats, both natural and anthropogenic, is of major importance for the development and implementation of effective management plans. The only predators known for this frog are the ctenid spider Ohvida vernalis (formerly referred as Ctenus vernalis, Novo et al. 1985) and a whip spider in the genus Phrynus (Alonso and Rodríguez 2003). Herein we report the first instance of predation by the Cuban Mosquitofish, Gambusia punctata (Poeciliidae), on E. zugi. This constitutes both the first record of fishes preying on Eleutherodactylus

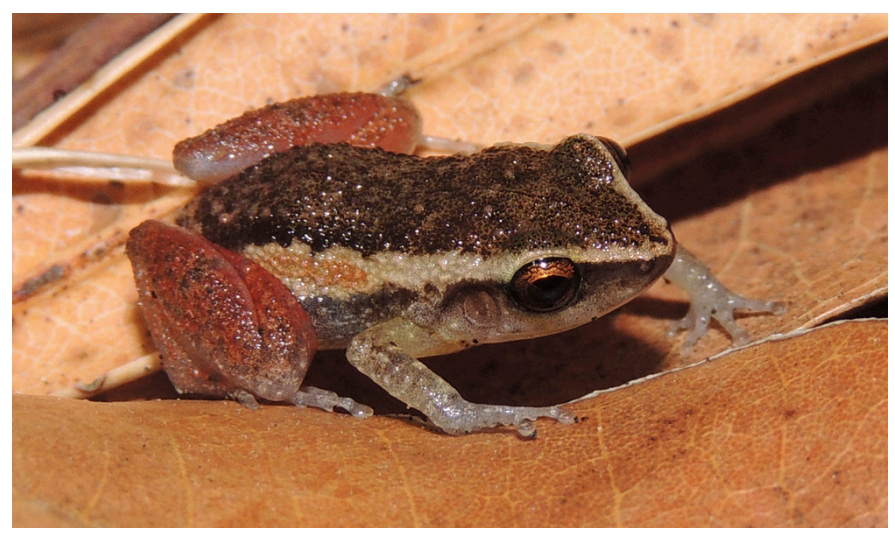

Fig. 1. Live Rosario Red-legged Frog (Eleutherodatylus zugi) from the same locality and exhibiting the same color pattern as the individual observed being predated by Cuban Mosquitofish (Gambusia punctata) on the Cajálbana Plateau, Pinar del Río Province. 


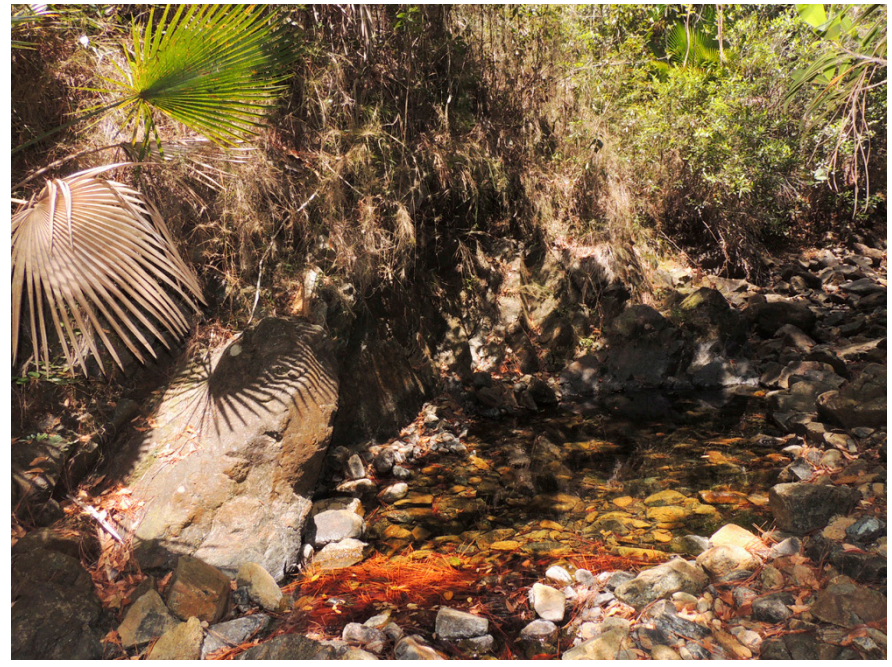

Fig. 2. Stream pool on the Cajálbana Plateau, Pinar del Río Province, where we observed predation by the Cuban Mosquitofish (Gambusia punctata) on a Rosario Red-legged Frog (Eleutherodatylus zugi).

frogs and the first record of frogs as prey of the mosquitofish genus Gambusia in the West Indies.

At $1124 \mathrm{~h}$ on 26 April 2015, we observed an Eleutherodactylus zugi (18 $\mathrm{mm}$ snout-vent length) being predated by Cuban Mosquitofish ( $G$. punctata) in a shallow pool (approximately $4 \mathrm{~m}$ long, $2 \mathrm{~m}$ wide, and $35 \mathrm{~cm}$ maximum depth) of a stream on the southern slope of the Cajálbana Plateau (22 46'50"N, $-83^{\circ} 26^{\prime} 21^{\prime \prime W}$; 150 m asl; datum: WGS 84), $450 \mathrm{~m} \mathrm{NE}$ of the biological station at the Cajálbana Floristic Reserve, Pinar del Río Province, Cuba (Figs. 2 and 3). When found, an adult female mosquitofish (64 mm total length, $55 \mathrm{~mm}$ standard length) (Figs. 4 and 5) had grabbed and entirely swallowed the left hindlimb of the frog, which was alive and trying to escape. A few minutes later, the fish released the frog and other smaller Gambusia commenced to attack it in a feeding-frenzy (Fig. 3). When collected, the frog had died and lost some flesh from the left hindlimb and the right forelimb (Fig. 5). In order to identify the frog, we collected it, presuming that the mosquitofish would otherwise consume it entirely. Both the frog and the largest female mosquitofish are deposited in the Ichthyological Collection of the Zoological Collections, Instituto de Ecología y Sistemática, La Habana, Cuba (voucher: CZACC-9.63).

In Cuba, the mosquitofish genus Gambusia comprises three currently recognized species (Ponce de León and Rodríguez 2010). Gambusia punctata (Fig. 4) is an endemic freshwater species widely distributed on the main island and on Isla de la Juventud, where it inhabits both lotic and lentic ecosystems in lowland and montane zones (Ponce de León and Rodríguez 2010). It is a relatively large species in the family Poeciliidae, with females attaining total lengths approaching $100 \mathrm{~mm}$ (Poey 1854; Ponce de León and Rodríguez 2010). It is a highly voracious and opportunistic surface-

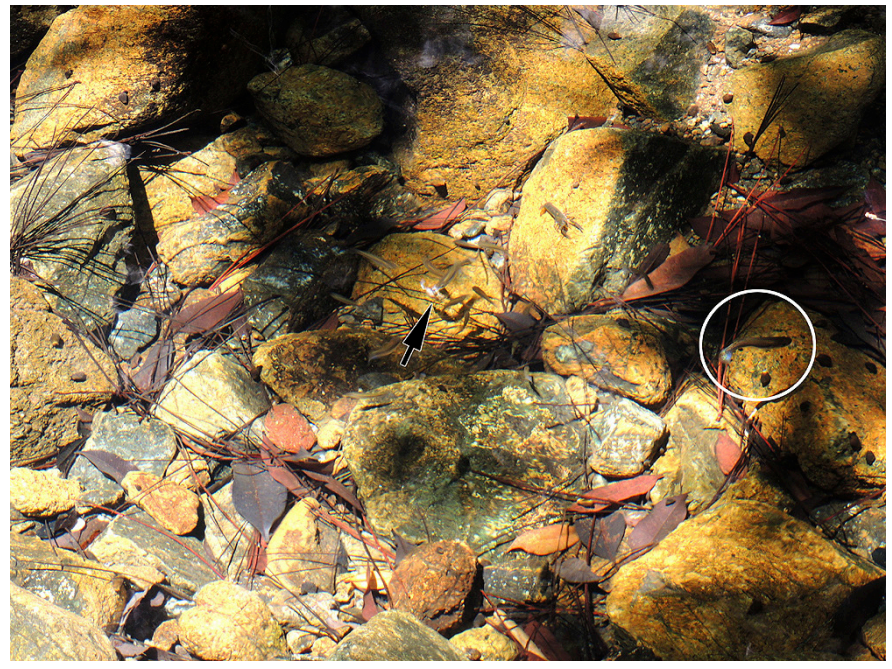

Fig. 3. Close-up view of the pool showing smaller Cuban Mosquitofish (Gambusia punctata) attacking a Rosario Red-legged Frog (Eleutherodatylus zugi) (arrow) after the largest female (white circle) had released it.

swimmer that feeds on insects and their larvae, arachnids, myriapods, mollusks, crustaceans, protozoans, and vegetable matter (Vergara 1992; Fong et al. 1996; Ponce de León and Rodríguez 2013). However, until now, no vertebrates had been reported as prey of this species.

The stream where we observed the predation event is one of the nearly 40 stream basins around the Cajálbana Plateau that fragment into pools or even dry up completely during the dry season. The area is characterized by red fossil ferritic soils and covered mostly by pinewoods and xeromorphic evergreen scrubwoods (Borhidi 1991). Frogs in the genus Eleutherodactylus develop in the egg and do not require water to reproduce. Probably due to the harsh conditions imposed by the dry season, enhanced by the characteristics of the soil and vegetation, non-riparian frogs of several species, including E. zugi, concentrate around the humid microhabitats associated with remaining pools in streambeds in remnant patches of gallery forest (TMRC, pers. obs.). We presume that this case of predation occurred when the frog accidentally jumped into the water while mosquitofish were actively foraging.

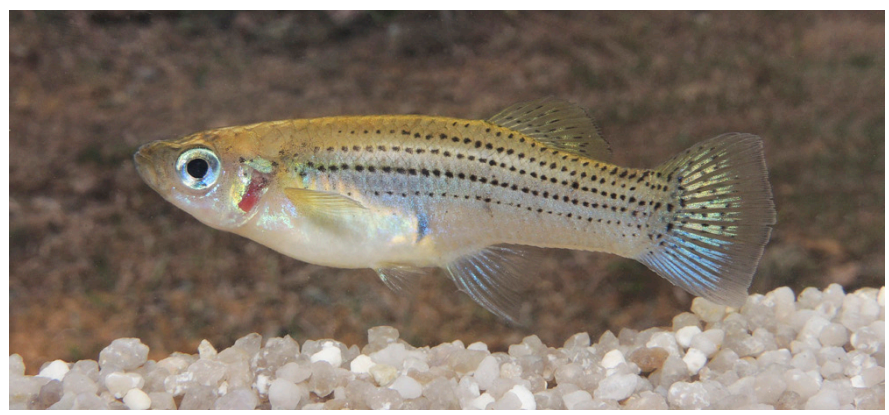

Fig. 4. Live Cuban Mosquitofish (Gambusia punctata) (largest female) observed predating a Rosario Red-legged Frog (Eleutherodatylus zugi) on the Cajálbana Plateau, Pinar del Río Province. 


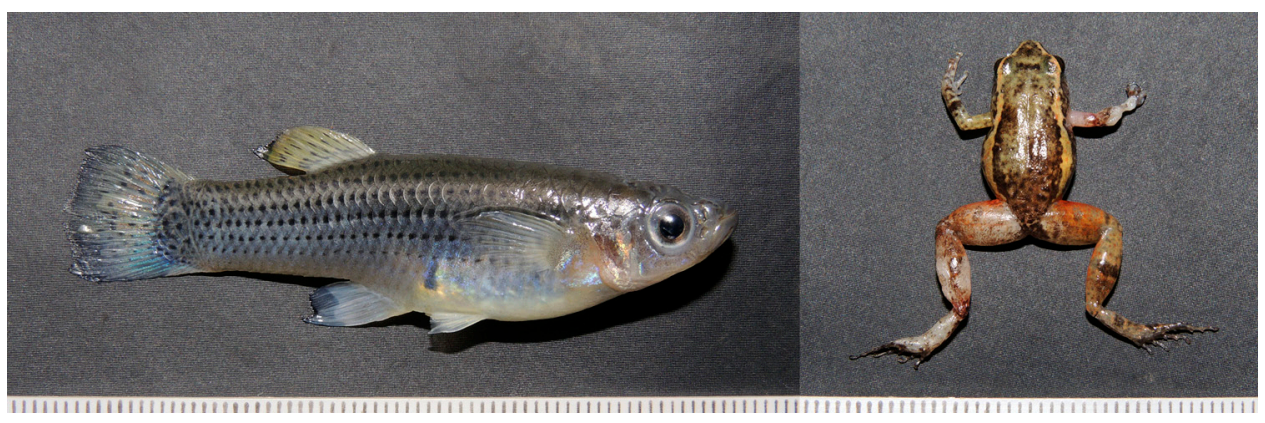

Fig. 5. Collected specimens of the Cuban Mosquitofish (Gambusia punctata) (largest female) and the Rosario Red-legged Frog (Eleutherodatylus zugi) from the Cajálbana Plateau, Pinar del Río Province.

\section{Acknowledgements}

We thank Sheila Rodríguez, Ansel Fong, Javier Torres, and Ruben Marrero for providing literature and/or useful comments on the manuscript. We also thank Sheyla Yong for helping us update the names of insect predators reported for Eleutherodactylus. We also thank the administration of the Mil Cumbres Protected Area, particularly custodians and the staff from the Cajálbana Floristic Reserve, for their hospitality during the expedition. This work was undertaken with the support of The Mohamed bin Zayed Species Conservation Fund (project no. 14059847) for the junior author and The Rufford Foundation (ID: 15393-1) for the senior author.

\section{Literature Cited}

Alfonso, Y.U., K. Pellicier Lopez, and D. Armijos-Ojeda. 2013. Endemic frog predation by the Cuban Lesser Racer, Caraiba andreae (Squamata: Dipsadidae), on La Melba, Alexander Von Humboldt National Park, eastern Cuba. Herpetology Notes 6:91-93.

Borhidi, A. 1991. Phytogeography and Vegetation Ecology of Cuba. Akadémiai Kiadó Zrt., Budapest, Hungary.

Díaz, L.M. and A. Cádiz 2008. Guía taxonómica de los anfibios de Cuba. AbcTaxa $4: 1-294+$ CD.

Díaz, L.M. and S.B. Hedges. 2015. Another new cryptic frog related to Eleutherodactylus varleyi Dunn (Amphibia: Anura: Eleuterodactylidae), from eastern Cuba. Solenodon 12:124-135.

Díaz, L.M., A. Cádiz, S. Villar, and F. Bermudez. 2014. Notes on the ecology and morphology of the Cuban Khaki Trope, Tropidophis hendersoni Hedges and Garrido (Squamata: Tropidophiidae), with a new locality record. Reptiles \& Amphibians 21:116-119.

Estrada, A.R. 2012. The Cuban Archipelago, pp. 113-125. In: R. Powell, and
R.W. Henderson (eds.), Island lists of West Indian amphibians and reptiles. Bulletin of the Florida Museum of Natural History 51:85-166.

Fong, A.G., G.G. Garcés, and E.F. Portuondo. 1996. Invertebrados en la alimentación de Gambusia punctata (Cyprinodontiformes: Poeciliidae) en aguas marinas. Cocuyo 5:13-14.

Hedges, S.B. and L.M. Díaz. 2004. Eleutherodactylus zugi. In: The IUCN Red List of Threatened Species Version 2014.3. <www.iucnredlist.org>.

Hedges, S.B. and L.M. Díaz. 2011. The conservation status of amphibians in the West Indies, pp. 31-47. In: A. Hailey, B. Wilson, and J. Horrocks (eds.), Conservation of Caribbean Island Herpetofaunas Volume 1: Conservation Biology and the Wider Caribbean. Brill, Leiden, The Netherlands.

Henderson, R.W. and R. Powell. 2009. Natural History of West Indian Amphibians and Reptiles. University Press of Florida, Gainesville.

Incháustegui, S.J., L.M. Díaz, and C. Marte. 2015. Dos especies nuevas de ranas del género Eleutherodactylus (Amphibia: Anura: Eleutherodactylidae) de La Hispaniola. Solenodon 12:136-149.

Novo Rodríguez, J., A.R. Estrada, and G. Alayón. 1985. Eleutherodactylus (Anura: Leptodactylidae) depredado por un aranéido. Miscelánea Zoológica 28:1-2.

Poey, F. 1854. Los guajacones, pececillos de agua dulce. Memorias de la Historia Natural de la Isla de Cuba 1:374-390.

Ponce de León, J.L. and R. Rodríguez. 2010. Peces Cubanos de la Familia Poeciliidae. Guia de Campo. Editorial Academia, La Habana.

Ponce de León, J.L. and R. Rodríguez. 2013. Segregación espacial en la comunidad de peces de agua dulce en un arroyo intermitente de Cuba. Revista Cubana de Ciencias Biológicas 2:24-30.

Powell, R. 2012. Hispaniola and Navassa, pp. 131-137. In: R. Powell, and R.W. Henderson (eds.), Island lists of West Indian amphibians and reptiles. Bulletin of the Florida Museum of Natural History 51:85-166.

Rivalta González, V., L. Rodríguez Schettino, C.A. Mancina, and M. Iturriaga. 2014. Amphibians of Cuba: Checklist and Geographic Distributions. Smithsonian Herpetological Information Service 145:1-48.

Vergara, R. 1992. Principales Características de la Ictiofauna Dulceacuicola Cubana. Editorial Academia, Ciudad de La Habana. 